\title{
Osteo- and Psoriatic Arthritis of the Hands
}

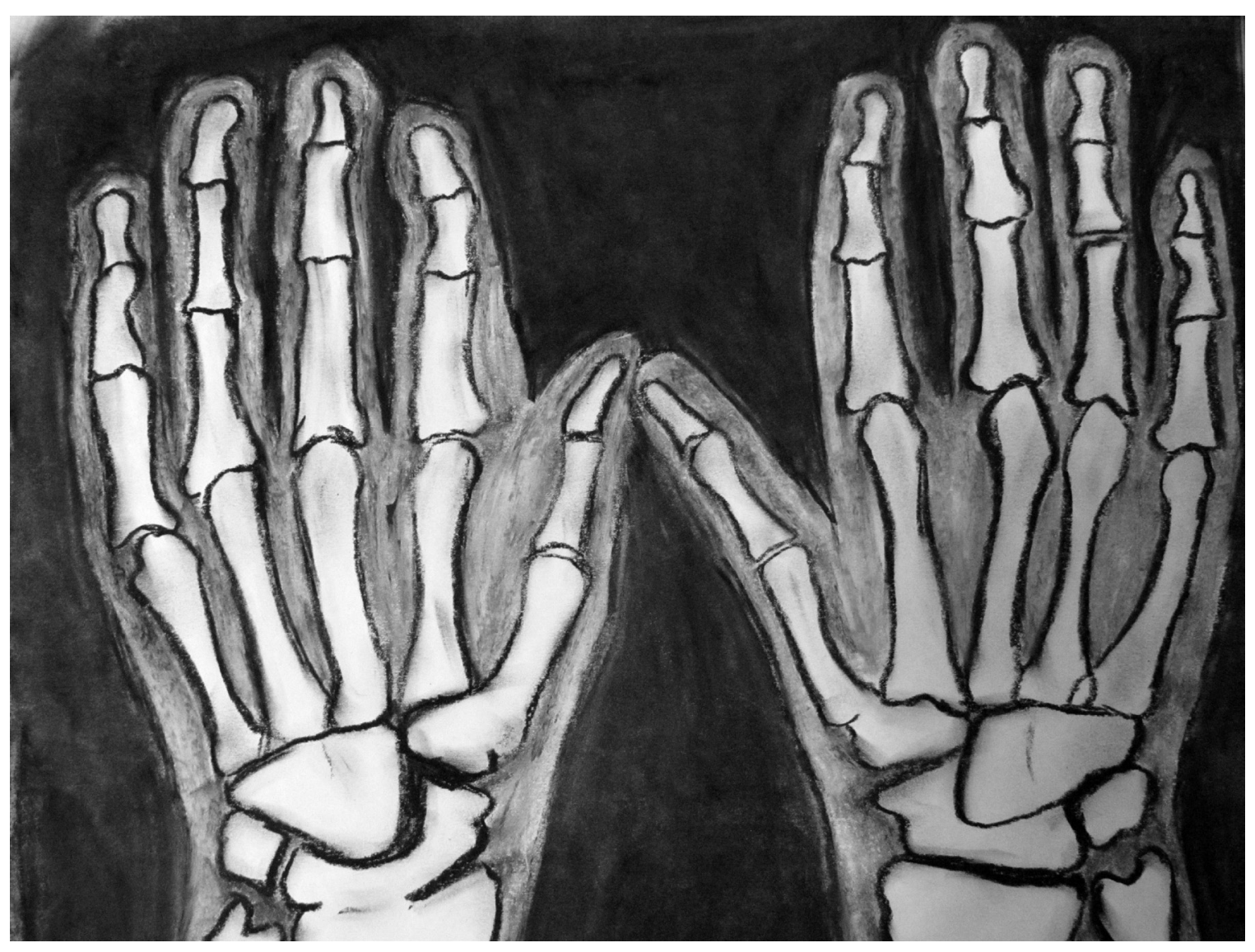

\section{Heather Thomas}

Class of 2014, Faculty of Medicine, Dalhousie University 